\title{
Factors that affect the welfare of the stone mining profession in the Tateli Village, Pineleng Sub District, Minahasa District
}

\author{
Novy J. Kasenda, Ismail Mokodompit, Ruhiyat, Leavy R. Pandey, Harty U.H.L. Koagouw \\ Department of Accounting, \\ Polytechnic of Manado Country \\ DOI: 10.31364/SCIRJ/v7.i10.2019.P1019706 \\ http://dx.doi.org/10.31364/SCIRJ/v7.i10.2019.P1019706
}

\begin{abstract}
The purpose of this research was to determine the factors that are very influential on the welfare of the stone miners' profession in the village of Tateli, Pineleng District, Minahasa Regency. The methodology used in this research is the Judgment Sampling method. Primary data were collected through questionnaires, interviews, and observations. The sample was determined as many as 40 people. Secondary data is taken from government regulations relating to research, documents, and activity manuals. Data is arranged in tabular form, and analyzed using the stepwise forward selection method, and Stepwise Backward elimination. The results showed that $Y=-0.225+0.580 \times 1+0.269 \times 9+0.204 \times 13$, the welfare of the stone mining profession in the village of Tateli, was determined by the availability of natural resources, income, and skills of each miner. Of these three factors, the availability of natural resources, income and skills has an influence on the welfare of the stone miners in Tateli Village, Pineleng SubDistrict, Minahasa District. From the results of this study, it can be concluded that with the stepwise Forward Selection method and Backward Elimination obtained 3 factors that affect the welfare of the stone mining profession in the village of Tateli, namely: the availability of natural resources, income and skills of each miner.
\end{abstract}

\section{Keywords: Resources, Income, Skills}

\section{Introduction}

The success or failure of the development of a nation in the era of globalization is determined by the main assets, namely: natural resources and human resources. Therefore, the role of human resource management is very important to regulate the process of utilizing human resources, and other resources effectively, and efficiently to achieve goals (Hasibuan, 2003). In simple terms, development can be interpreted as an effort, or a process to make changes for the better. In its implementation, development is multidimensional, and has various complexity problems. The development process occurs in all aspects of community life, both economic, political, social and cultural aspects. Today's contemporary thinking has re-placed human beings as the subject or center of the development process. Development can be interpreted, as a process of change towards a better state, through planned efforts. Development is a renewal, which is also a form of change in the desired direction, but more related to values, or value systems. Development is oriented to the attention of the community, and families who live below the poverty line, namely; people or families who have not been able to meet material needs, and to the rich groups are expected to channel sources of income to families who are less able.

National development activities are directed, to empower people and families to get out of the cycle of poverty and social welfare which have become major phenomena. This national development paradigm arises naturally from reality, such as population growth, utilization of natural resources, and the potential of existing resources (Anonim, 1998). The family as the smallest unit in society, has a very important role in creating quality human beings. If the family is viewed as an institution, then according to Leibo family (1994), is a pattern of behavior associated with functions to reduce offspring, and serves as a completeness of society in shaping its identity. Family according to Usman (1998), is the smallest social unit in society, because between family and society there is a reciprocal relationship, meaning that the existence and dynamics that grow in family life are influenced, and affect people's lives. In human life, welfare is something that individuals, groups and nationals want to achieve.

In this regard, in carrying out development activities, consideration of efforts to meet the needs of the wider community must be a major concern. Therefore, one of the main indicators to measure, the success or failure of a development process, namely: to what extent or how much the level of community needs can be met, both directly and indirectly. It can be directly seen from how the community can easily enjoy the fruits of development.

Development is a process of continuous renewal, with a continuous process of a situation that is considered better that is the goal of development programs in each country. Development process, is a socio-cultural change. So that development becomes a 
process that can move forward on its own strength (self sustaining process), it depends on humans and their social structure. This means that development is not only conceptualized as a government effort, but development depends on an "inner will" process of self-emancipation, and a creative participation in the development process, only possible because of the process of maturity.

Social inequality due to political and economic development can be translated as the result of a process that encourages the concentration of wealth and power that can grow peripheral communities (Periphery) which have weak bargaining power. While other groups of social science experts see the emergence of social inequality from a different perspective. This group sees that social inequality arises in the community due to an injustice in the selection of factors that influence the community.

On the one hand, the tateli village stone family in general is a family that lives within the limitations of both socialization opportunities, strata of life with other families and even polarization that is not desired by the Tateli Village stone mining family. On the other hand, the life of the tateli village family of stone miners requires attention and seriousness in all aspects of life including the availability of natural resources, climate and natural changes, equipment and marketing, transportation, communication, health, places of worship and income, and the nature of the business, dependency profession, education, skills, institutions and mental attitude of the community itself

Tourism development in this area is also multi-dimensional, and has various complexity problems. The rapid and competitive development of tourism development in this area has changed the distribution of income in every field of work in the village of Tateli - Minahasa. As a village that has the potential for coastal tourism, the development of the tourism industry along the coast of this village has had an external impact, resulting in mobility and changes in the composition of the business sectors of the Tateli village community. Significant changes in the field of community businesses occurred in communities that previously were fishermen, and to survive (more prosperous), then they moved to become stone miners.

If this condition continues, it will cause an imbalance of the working profession in this area, which in turn can damage all fields of business (including tourism) in the village of Tateli. Another thing that is no less important is that the process of management / production of stone in the village of Tateli, is only done manually, and conventionally with a high level of occupational safety risk, because in general the stone miners do not really understand the safer production process techniques, and avoid things that are not wanted. This production process is certainly not possible to just leave it alone, but there needs to be concern from the investor $/$ private sector in the framework of mining management. The stone production process by using modern equipment in order to be more spurred on increasing the income of the miners to be able to increase welfare even better. The mining process above, of course, is inseparable from the availability of stone mining workers, who on average do not have proper education.

The impact of externalities in tourism development, encourages researchers to know the factors that affect the welfare of stone miners, as a profession that can be sustainable. Starting from the background of the problem, the formulation of the problem that is the focus of this research is formulated as follows:

1. Does the availability of natural resources, climate and natural changes, equipment and marketing affect the welfare of the stone mining community in Tateli Village?

2. Do transportation, communication, health, Ibadan location and income affect the welfare of the stone mining community in Tateli Village?

3. Do the factors of business nature, professional dependence, education, skills, institutions and mental attitude affect the welfare of the stone mining community in Tateli Village?

\section{Research Methods}

In analyzing the factors that influence the welfare of the stone mining profession in the village of Tateli, researchers used a predictor variable that was truly independent (small correlated) so that the best model could be found. For this purpose, researchers used regression analysis with the stepwise method. To analyze the ongoing profession of stone miners in the village of Tateli, researchers used a descriptive analysis, so that the role of each factor affecting the welfare of the stone mining profession in the village of Tateli, Pineleng Sub-District, Minahasa District can be explained for the development and continuation of the profession

\section{A. Population and Sample}

The selection of nonprobability samples is done based on the way of "Judgment Sampling" decision. The population of people who work as stone miners in the village of Tateli is 85 people. For the purposes of this research, researchers set respondents as many as 40 miners respondents, who are considered to be representative.

\section{B. Operational Definitions of Variables and Indicators}

The related variables in this study are as follows :

$\mathrm{Y}=$ Stone Miner's Professional Welfare, which is the aggregate condition of the satisfaction of the stone miners. The measurement is based on the level of job satisfaction of the stone miners. 
$\mathrm{X}_{1}=$ Availability of Natural Resources, namely the availability of stones to meet the needs of miners today, and their future. The measurement is based on the response of miners with a linkert scale

$\mathrm{X}_{2}=$ Climate and Natural Change, namely the influence of climate and natural change on rock mining activities. The measurement is based on the response of miners with a linkert scale.

$\mathrm{X}_{3}=$ Equipment, namely the availability of equipment for rock mining activities. The measurement is based on the response of miners with a linkert scale.

$\mathrm{X}_{4}=$ Marketing, namely the availability of markets for the results of rock mining activities. The measurement is based on the response of miners with a linkert scale.

$\mathrm{X}_{5}=$ Transportasi Transportation, namely the availability of transportation for transportation of the results of rock mining activities. The measurement is based on the response of miners with a linkert scale.

$\mathrm{X}_{6}=$ Communication, namely the influence of communication factors on rock mining activities. The measurement is based on the response of miners with a linkert scale

$\mathrm{X}_{7}=$ Health, namely the influence of health factors on rock mining activities. The measurement is based on the response of miners with a linkert scale.

$\mathrm{X}_{8}=$ Place of Worship, namely the availability of places of worship for rock mining activities. The measurement is based on the response of miners with a linkert scale.

$\mathrm{X}_{9}=$ Revenue, which is the influence of income factors on rock mining activities. The measurement is based on the response of miners with a linkert scale.

$X_{10}=$ Business Nature, namely the influence of income factors on rock mining activities. The measurement is based on the response of miners with a linkert scale.

$\mathrm{X}_{11}=$ Dependence on the profession, namely the dependence of miners on the stone mining profession. The measurement is based on the response of miners with a linkert scale.

$\mathrm{X}_{12}=$ Education Level, i.e. the influence of formal education level on rock mining activities. The measurement is based on the response of miners with a linkert scale.

$\mathrm{X}_{13}=$ Skills, namely the influence of skills on the results of rock mining activities. The measurement is based on the response of miners with a linkert scale.

$\mathrm{X}_{14}=$ Institutional, namely the influence of institutional factors on rock mining activities. The measurement is based on the response of miners with a linkert scale.

$\mathrm{X}_{15}=$ Attitude and Mental, namely the influence of miner's attitude and mental factors on the results of rock mining activities. The measurement is based on the response of miners with a linkert scale.

\section{Data Analysis}

The best model can be obtained from the variables studied using the forward stepwise elimination method (Forward Stepwise Regression Procedure). The forward elimination procedure is one of the best model selection procedures in regression with the elimination of independent variables that build the model in stages, Dillon \& Goldstein (1984).

The steps are as follows:

1. Make a simple regression model for each independent variable. Then, for each model, a slope test is performed with an $\mathrm{F}$ test. We compare the highest $\mathrm{F}$ values, for example FL, with certain significant $\mathrm{F}$ values from the table, for example F0

a. If $\mathrm{FL}<\mathrm{F} 0$, it means that there are no independent variables selected.

b. If $\mathrm{FL}>\mathrm{F} 0$, enter the independent variable $\mathrm{L}$ into the model.

2. If at stage 1 there are independent variables entered (for example L), then we make a regression model with two independent variables, where one of them is the variable $\mathrm{L}$, for example the independent variables $\mathrm{L}$ and $\mathrm{K}$. Then, we do a partial $\mathrm{F}$ test: $\mathrm{FK}=$ then we compare the highest $\mathrm{F}$ values, for example FK with certain significant standard $\mathrm{F}$ values from the table, for example F0.

a. Jika FK $<$ F0, that is, only the independent variables that succeed in stage 1 are used in the model.

b. Jika FK > F0, enter the independent variable $\mathrm{K}$ entered into the model.

3. if in stage 2 there is an independent variable entered (for example $\mathrm{K}$ ), then stepwise checks whether there are independent variables already present in the excluded model. We do a partial F test: FL.

a. If $\mathrm{FL}<\mathrm{F} 0$, that is, the independent variable $\mathrm{L}$ is excluded from the model.

b. If $\mathrm{FK}>\mathrm{F} 0$, that is, the independent variables $\mathrm{L}$ and $\mathrm{K}$ are included in the model.

4. For example, the independent variable $\mathrm{L}$ is maintained. So, now the independent variables $\mathrm{L}$ and $\mathrm{K}$ are used in the model. Furthermore, the stage repeats until there are no more independent variables added or removed. That is, the work has been completed. 


\section{Discussion}

Table 3.1. The Situation of Tateli Villagers According to

Level of Education in 2018

\begin{tabular}{|c|l|c|c|}
\hline Number. & \multicolumn{1}{|c|}{ Level of education } & Amount & Percent \\
\hline 1 & Did not graduate elementary school & 221 & $4 \%$ \\
\hline 2 & Primary school & 752 & $13,6 \%$ \\
\hline 3 & Junior high school & 1.553 & $28,2 \%$ \\
\hline 4 & Senior High School & 2.739 & $49,7 \%$ \\
\hline 5 & Diploma I & 27 & $0,5 \%$ \\
\hline 6 & Diploma II & 64 & $1,2 \%$ \\
\hline 7 & Diploma III & 51 & $0,9 \%$ \\
\hline 8 & Bachelor degree & 92 & $1,7 \%$ \\
\hline 9 & Strata 2 & 11 & $0,2 \%$ \\
\hline 10 & Strata 3 & & $0 \%$ \\
\hline \multicolumn{2}{|c|}{ Total } & $\mathbf{5 . 5 1 0}$ & $\mathbf{1 0 0 \%}$ \\
\hline
\end{tabular}

Source: Statistics of Tateli Village in 2018

Table 3. 2. Situation of Tateli Villagers According to Profession / Livelihood in 2018

\begin{tabular}{|c|l|r|c|}
\hline Number. & \multicolumn{1}{|c|}{ Profession } & Amount & Percent \\
\hline 1 & Farmers & 2,178 & $39.5 \%$ \\
\hline 2 & Teacher & 274 & $5.0 \%$ \\
\hline 3 & Private Servants & 443 & $8.0 \%$ \\
\hline 4 & Private employees & 399 & $7.2 \%$ \\
\hline 5 & $\begin{array}{l}\text { Indonesian National Army } \\
\text { Indonesian Police }\end{array}$ & 477 & $8.7 \%$ \\
\hline 6 & Retired & 213 & $3.9 \%$ \\
\hline 7 & Workers and Miners & 382 & $6.9 \%$ \\
\hline 8 & Breeder & 142 & $2.6 \%$ \\
\hline 9 & Entrepreneur & 277 & $5.0 \%$ \\
\hline 10 & Industrial / Furniture Craftsman & 68 & $1.2 \%$ \\
\hline 11 & Tailor & 20 & $0.4 \%$ \\
\hline 12 & Construction workers & 308 & $5.6 \%$ \\
\hline 13 & Etc & 328 & $6.0 \%$ \\
\hline
\end{tabular}

Source: Statistics of Tateli Village in 2018

\section{A. Description of Variables}

From the results of the research that has been done, it can be explained the description of the variables used in this study. This description is based on the model that has been displayed in the flow of thought in accordance with the concepts and theories put forward. The results of the Descriptive Statistics analysis conducted by researchers using the Analysis ToolPak - VBA from MS Excel on the research variables are presented in table 3.3: 
Table 3. 3 Descriptions of Research Variables

\begin{tabular}{|c|c|c|c|c|c|c|c|c|c|c|}
\hline Category & \multicolumn{2}{|l|}{ Variablel } & Mean & Median & Mode & Range & Min & Max & Sum & Count \\
\hline \multirow{2}{*}{$\begin{array}{l}\text { Natural } \\
\text { Conditions }\end{array}$} & Avability $H \& D$ & $\mathrm{X}_{1}$ & 4.2 & 4 & 5 & 2 & 3 & 5 & 168 & 40 \\
\hline & $\begin{array}{c}\text { Climate and Natural } \\
\text { Change }\end{array}$ & $x_{2}$ & 3.5 & 3 & 3 & 3 & 2 & 5 & 141 & 40 \\
\hline \multirow{6}{*}{$\begin{array}{l}\text { Facilities and } \\
\text { Infrastructure }\end{array}$} & Equipment & $x_{3}$ & 4.1 & 4 & 4 & 2 & 3 & 5 & 163 & 40 \\
\hline & Marketing & $\mathrm{X}_{4}$ & 3.4 & 3 & 3 & 3 & 2 & 5 & 136 & 40 \\
\hline & Transportation & $\mathrm{X}_{5}$ & 3.9 & 4 & 4 & 3 & 2 & 5 & 155 & 40 \\
\hline & Communication & $\mathrm{X}_{6}$ & 3.4 & 3 & 3 & 3 & 2 & 5 & 135 & 40 \\
\hline & Health & $x_{7}$ & 3.9 & 4 & 4 & 2 & 3 & 5 & 156 & 40 \\
\hline & Worship Place & $\mathrm{X}_{8}$ & 3.6 & 4 & 4 & 3 & 2 & 5 & 144 & 40 \\
\hline \multirow{3}{*}{$\begin{array}{l}\text { Economic } \\
\text { Factors }\end{array}$} & Income & $\mathrm{X}_{9}$ & 4.1 & 4 & 4 & 2 & 3 & 5 & 162 & 40 \\
\hline & Nature of Business & $\mathrm{X}_{10}$ & 3.4 & 3 & 3 & 3 & 2 & 5 & 135 & 40 \\
\hline & $\begin{array}{c}\text { Dependence on the } \\
\text { Profession }\end{array}$ & $\mathrm{X}_{11}$ & 4.0 & 4 & 4 & 2 & 3 & 5 & 160 & 40 \\
\hline \multirow{4}{*}{ Social Factors } & Education & $X_{12}$ & 3.7 & 4 & 4 & 3 & 2 & 5 & 148 & 40 \\
\hline & The Skills & $\mathrm{X}_{13}$ & 3.9 & 4 & 5 & 3 & 2 & 5 & 157 & 40 \\
\hline & $\begin{array}{l}\text { Structure \& } \\
\text { Institution }\end{array}$ & $X_{14}$ & 3.4 & 3 & 3 & 3 & 2 & 5 & 135 & 40 \\
\hline & Mental Attitude & $X_{15}$ & 3.9 & 4 & 4 & 3 & 2 & 5 & 156 & 40 \\
\hline \multicolumn{2}{|c|}{ The Welfare of the Stone Miners } & $\mathrm{Y}$ & 4.1 & 4 & 5 & 2 & 3 & 5 & 164 & 40 \\
\hline
\end{tabular}

Source: Processed Data, 2018

From the 40 samples taken, the highest total score is in the SDA Availability variable (x1), which is 85 . The large total score in the SDA Availability variable (x1) causes the mean (mean) on this variable to be greater than the other variables. This explains the variable Availability of natural resources (x1), received greater attention from the sample when compared with other variables. The lowest total score (sum), which is 135 is in the Marketing variable (x4), Communication variable (x6), Business Nature variable (x10), and Institutional variable (x14). This explains, the four variables received less attention from the sample when compared with other variables.

Nilai tengah (median) yang berada tepat pada tengah-tengah skala yaitu 3 terjadi pada variabel Iklim dan Perubahan Alam $\left(\mathrm{x}_{2}\right)$, variabel Pemasaran $\left(\mathrm{x}_{4}\right)$, variabel Komunikasi $\left(\mathrm{x}_{6}\right)$, variabel Sifat Usaha $\left(\mathrm{x}_{10}\right)$, dan variabel Kelembagaan $\left(\mathrm{x}_{14}\right)$. Hal ini menjelaskan, lima variabel tersebut memiliki distribusi normal sempurna. Variabel yang lain memiliki nilai tengah 4 yang menjelaskan adanya kecondongan positif dari sampel.

The most frequently occurring value (mode) with the highest score is in the Availability of Natural Resources variable (x1), Skill variable (x13), and Batu Miners Professional Welfare variable (Y). This explains, these three variables get the attention of the sample when compared with other variables. The greatest value ( $\max$ ) occurs in all variables. The smallest value (min) varies in score 2 and score 3 . This variation causes the distance (range) between the highest value and lowest value also varies.

The results of the stepwise regression analysis of the factors that influence the welfare of the stone mining profession in the village of Tateli using SPSS software are as follows:

1. First step: Calculate the correlation coefficient of each independent variable with the dependent variable. The correlation coefficient $\mathrm{x} 1$ with $\mathrm{Y}$ is closest to $|1|$, so the variable $\mathrm{x} 1$ is the first variable that enters the model.

2. Second step: Estimation of the regression model with independent variables $\mathrm{x} 1$.

\section{Coefficients ${ }^{a}$}

\begin{tabular}{|c|c|c|c|c|c|}
\hline \multirow[b]{2}{*}{ Model } & \multicolumn{2}{|c|}{$\begin{array}{c}\text { Unstandardized } \\
\text { Coefficients }\end{array}$} & \multirow{2}{*}{$\begin{array}{c}\text { Standardi } \\
\text { zed } \\
\text { Coefficien } \\
\text { ts } \\
\text { Beta }\end{array}$} & \multirow[b]{2}{*}{$\mathrm{t}$} & \multirow[b]{2}{*}{ Sig. } \\
\hline & $\mathrm{B}$ & Std. Error & & & \\
\hline $\begin{array}{l}\text { (Constant) } \\
\times 1\end{array}$ & $\begin{array}{l}-.250 \\
1.036\end{array}$ & $\begin{array}{l}.276 \\
.065\end{array}$ & .933 & $\begin{array}{r}-.905 \\
15.989\end{array}$ & $\begin{array}{l}.371 \\
.000\end{array}$ \\
\hline
\end{tabular}

a. Dependent Variable: $Y$

Because $\mid$ thit $\mid>\mathrm{t} 1-\alpha / 2$; db.error or $\mathrm{p}$-value $<\alpha(=5 \%)$, then the significant variable $\mathrm{x} 1$ enters the model. 
3. Third step: Calculate the partial correlation of the remaining independent variables with $\mathrm{Y}$, as the control variable is a variable that has entered the model, namely $\mathrm{x} 1$. Based on SPSS output, $\mathrm{x} 13$ has the partial correlation coefficient closest to $|1|$, so $\mathrm{x} 13$ enters the model after $\mathrm{x} 1$.

4. Step four: Estimating the regression model, by entering the variable $\mathrm{x} 13$ after $\mathrm{x} 1$.

\section{Coefficients ${ }^{a}$}

\begin{tabular}{|c|c|c|c|c|c|c|}
\hline \multirow{2}{*}{\multicolumn{2}{|c|}{ Model }} & \multicolumn{2}{|c|}{$\begin{array}{l}\text { Unstandardized } \\
\text { Coefficients }\end{array}$} & \multirow{2}{*}{$\begin{array}{c}\text { Standardi } \\
\text { zed } \\
\text { Coefficien } \\
\text { ts } \\
\text { Beta }\end{array}$} & \multirow[b]{2}{*}{$\mathrm{t}$} & \multirow[b]{2}{*}{ Sig. } \\
\hline & & $\mathrm{B}$ & Std. Error & & & \\
\hline & (Constant) & -.224 & .255 & & -.878 & .386 \\
\hline & $\times 1$ & .833 & .094 & .751 & 8.835 & .000 \\
\hline & $\times 13$ & .210 & .076 & .236 & 2.774 & .009 \\
\hline
\end{tabular}

a. Dependent Variable: $Y$

Because $\mid$ thit $\mid>\mathrm{t} 1 \mathrm{-a} / 2$; db.error or $\mathrm{p}$-value $<\alpha$, then the significant variables $\mathrm{x} 1$ and $\mathrm{x} 13$ enter the model.

5. Step five: Calculate the partial correlation of the remaining variables with $\mathrm{Y}$, as the control variables are $\mathrm{x} 1$ and $\mathrm{x} 13$. The partial correlation $\mathrm{x} 9$ with $\mathrm{Y}$ is closest to $|1|$, so $\mathrm{x} 9$ enters the model, after $\mathrm{x} 1$ and $\mathrm{x} 13$.

6. Step six: Estimating the regression model, by entering the variables $\mathrm{x} 9$ after $\mathrm{x} 1$ and $\mathrm{x} 13$

\section{Coefficients $a$}

\begin{tabular}{|c|c|c|c|c|c|c|}
\hline \multirow{2}{*}{\multicolumn{2}{|c|}{ Model }} & \multicolumn{2}{|c|}{$\begin{array}{c}\text { Unstandardized } \\
\text { Coefficients }\end{array}$} & \multirow[t]{2}{*}{$\begin{array}{c}\text { Standardi } \\
\text { zed } \\
\text { Coefficien } \\
\text { ts } \\
\text { Beta }\end{array}$} & \multirow[b]{2}{*}{$\mathrm{t}$} & \multirow[b]{2}{*}{ Sig. } \\
\hline & & $\mathrm{B}$ & Std. Error & & & \\
\hline \multirow[t]{4}{*}{1} & (Constant) & -.225 & .242 & & -.928 & .360 \\
\hline & $\times 1$ & .580 & .144 & .523 & 4.039 & .000 \\
\hline & $\times 13$ & .204 & .072 & .229 & 2.835 & .007 \\
\hline & $\times 9$ & .269 & .119 & .260 & 2.255 & .030 \\
\hline
\end{tabular}

a. Dependent Variable: $Y$

Because $\mid$ thit $\mid>\mathrm{t} 1-\mathrm{a} / 2$; db.error or $\mathrm{p}$-value $<\alpha$, then the variables $\mathrm{x} 1$ and $\mathrm{x} 9$ and $\mathrm{x} 13$ are significantly entered into the model.

7. Seventh step: Calculate the partial correlation of the remaining variables with $\mathrm{Y}$, as the control variables are $\mathrm{x} 1$ and $\mathrm{x} 9$ and $\mathrm{x} 13$. The partial correlation $\mathrm{x} 3$ with $\mathrm{Y}$ is closest to $|1|$, so $\mathrm{x} 3$ enters the model, after $\mathrm{x} 1$ and $\mathrm{x} 9$ and $\mathrm{x} 13$.

8. Step eight: Estimating the regression model, by entering the variables $\mathrm{x} 3$ after $\mathrm{x} 1$ and $\mathrm{x} 9$ and $\mathrm{x} 13$

\section{Coefficients ${ }^{a}$}

\begin{tabular}{|c|c|c|c|c|c|c|}
\hline \multirow{2}{*}{\multicolumn{2}{|c|}{ Model }} & \multicolumn{2}{|c|}{$\begin{array}{c}\text { Unstandardized } \\
\text { Coefficients }\end{array}$} & \multirow{2}{*}{$\begin{array}{c}\text { Standardi } \\
\text { zed } \\
\text { Coefficien } \\
\text { ts } \\
\text { Beta }\end{array}$} & \multirow[b]{2}{*}{$\mathrm{t}$} & \multirow[b]{2}{*}{ Sig. } \\
\hline & & $\mathrm{B}$ & Std. Error & & & \\
\hline \multirow[t]{5}{*}{1} & (Constant) & -.528 & .299 & & -1.762 & .087 \\
\hline & $\times 1$ & .518 & .145 & .467 & 3.568 & .001 \\
\hline & $\times 13$ & .217 & .071 & .244 & 3.074 & .004 \\
\hline & $\times 9$ & .295 & .118 & .285 & 2.507 & .017 \\
\hline & $\times 3$ & $9.950 E-02$ & .060 & .086 & 1.649 & .108 \\
\hline
\end{tabular}

a. Dependent Variable: $Y$

Because $\mid$ thit $\mid<\mathrm{t} 1-\mathrm{a} / 2$; db.error or $\mathrm{p}$-value $>\alpha$, then the $\mathrm{x} 3$ variable is excluded from the model. The procedure is complete because the best model has been obtained by the stepwise method, namely the model in step six $(6): Y=-0.225+0.580 x 1+0.269 x 9$ 
$+0.204 \times 13$. With this model it can be said that: the welfare of the Tateli village stone mining profession, is determined by the availability of natural resources, income, and skills of each miner. Of these three factors, Availability of Natural Resources has the largest multiplier, namely 0.580 then Income with a multiplier of 0.269, and Skill with a multiplier of 0.204.

From the village statistical data, the number of laborers and miners in Tateli village, Pineleng Subdistrict, Minahasa Regency was 382 people, including 85 stone miners. The miner of the village of Tateli, works on 110 hectares of mining land with an average daily income of Rp. 210,000. Generally, the miners of this tateli village have family ties, so that in doing the work, they help each other and share with each other, about hereditary skills. It's just that this condition illustrates the stone miners in the village of Tateli, able to live properly with a relatively higher level of welfare, when compared to other professions, such as: farmers, fishermen, civil servants, artisans, and others.

If the government has the policy to develop this profession, it will cause even more Tateli villagers to switch professions to become stone miners. If this condition continues, it will cause an imbalance in the carrying capacity of the environment in this area. This certainly happened because of one factor, namely the Availability of Natural Resources is limited.

The average daily income of Rp. 210,000 is an attraction for the stone mining profession. Significant changes in the field of community business have occurred in communities that were previously fishermen, and in order to survive (to be more prosperous) they then moved to become stone miners. The impact of externalities in the development of tourism in this area, will also cause more residents of the village of Tateli, who switched professions to become a stone miner. This will cause an imbalance in the carrying capacity of the environment, and in turn can damage all fields of business (including tourism) in the Tateli village.

To overcome this problem, researchers place the skill factor as a factor that must be developed. The intended development is to provide training, as well as counseling on ways of mining more skilled / professional stones, counseling on work safety, pilot training in the manufacture of processed household appliances, with the main raw material of stone, which has a relatively higher economic value if compared to the current production of stone miners. The products in question such as: interior and exterior equipment, as well as souvenirs for tourists. The development of the skills of stone miners, as such, will reduce the use of limited natural resources, and at the same time increase income. This means that the welfare of the stone mining profession will improve, and can become a sustainable profession.

\section{Conclusion}

With the stepwise method, the best model is obtained: $\mathrm{Y}=-0.225+0.580 \mathrm{x} 1+0.269 \times 9+0.204 \times 13$ It can be said that the welfare of the Tateli village stone mining profession is determined by the availability of natural resources, income, and skills of each miner.

\section{Suggestion}

1. The skills factor must be developed. The intended development is to provide a pilot manufacturing of processed products, with the main raw material of stone, which has a relatively higher economic value. The product in question is interior and exterior equipment, as well as souvenirs for tourists.

2. Pengembangan keterampilan para penambang batu seperti itu akan menekan penggunaan sumberdaya alam dan sekaligus dapat meningkatkan pendapatan. Ini berarti akan meningkatan kesejahteraan profesi penambang batu dan dapat menjadi suatu profesi yang berkelanjutan.

\section{Referensi}

Anonim, 2008. Reviewing the concept of the welfare gap. Regional Directorate 1, Deputy for Regional Development and Regional Autonomy, Jakarta.

Dessler, G. 2007. Human Resource Management, Prentice-Hall, New Jersey.

Djojohadikusumo, S., 1985. Indonesia in the Development of the World Now, and the Future. LP3ES, Jakarta.

Hasibuan, S.P. 2003. Human Resource Management, Basis and Keys to Success, Haji Mas Agung, Jakarta. 2003. Human Resource Management, Bumi Aksara, Jakarta.

Harton, B. dan Hunt, 1990. Sociology. PT. Raja Grafindo Yakarta.

Manurung, V. 1983. An Overview of the Criteria of Small Fishermen, and the Problems of Their Development in Java. In Proceedings of the Indonesian Fisheries Socio-Economic Workshop.. Cisarua November 1982. Balitbang Departemen Pertanian. Jakarta.

Moenir, A.S. 1988. Work Leadership. Bina Aksara Jakarta.

Prawirosentomo, S. 2005. Employee Performance Policy, BPFE-UGM, Yogyakarta.

Prijono dan Pranarka. 1996. Empowerment: Concepts, Wisdom and Implementation, CSIS, Jakarta.

Purna I dan Adhyawarman. 2009. Indeks Human Development and Population Mobility. Republic of Indonesia State Secretariat, Jakarta.

Suharto, E. 2005. Building Communities, Empowering People: Strategic Studies of Social Welfare Development and Social Work, Bandung: Refika Aditama.

WWW.scirj.org

(C) 2019, Scientific Research Journal

http://dx.doi.org/10.31364/SCIRJ/v7.i10.2019.P1019706 
Suharto, E. 2005. Public Policy Analysis: A Practical Guide to Assessing Problems and Social Policy, Bandung: Alfabeta. Soegijoko, S., 2005. Concepts and Approaches for Urban Development in Indonesia.

Urban and Regional Development Institute and Sugijanto Soegijoko Foundation. Jakarta.

Usman, S. 1998. Empowering the community, Rineka Cipta, Jakarta. 